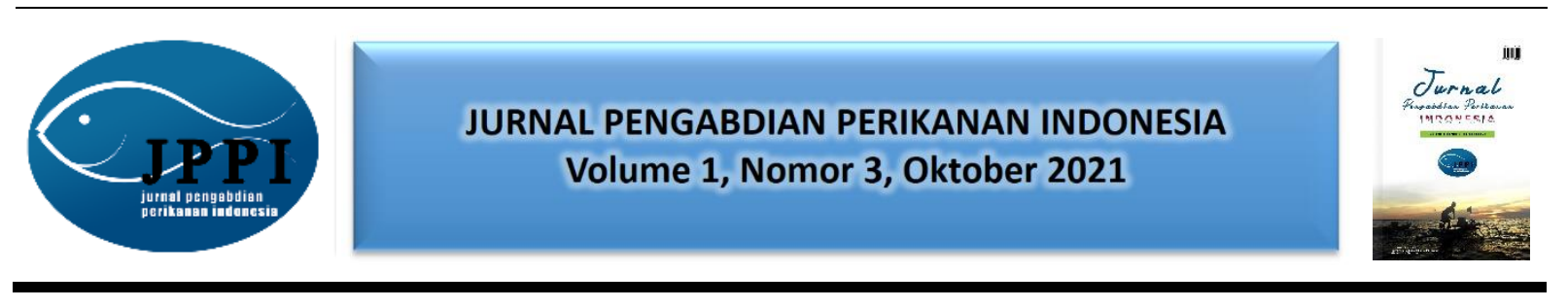

\title{
PEMANFAATAN BAHAN BAKU LOKAL SEBAGAI PAKAN IKAN UNTUK KELOMPOK BUDIDAYA IKAN HIAS (AQUA FISH) DI KOTA TERNATE
}

\author{
Rovina Andriani*, Fatma Muchdar, Khamsiah Ahmad, Juharni \\ Program Studi Budidaya Perairan Universitas Khairun Ternate \\ Jl. Pertamina Kampus II Unkhair Gambesi Kota Ternate Selatan
}

*Alamat korespondensi : vina.fisheries@gmail.com

(Tanggal Submission: : 9 September 2021, Tanggal Accepted : 31 Oktober 2021)

\begin{abstract}
Keyword : Abstrak :
Bahan baku Pakan merupakan salah satu komponen strategis yang sangat menentukan keberhasilan lokal, pakan usaha budidaya. Pada kegiatan tersebut, hampir 60-70\% dari total biaya produksi ikan, kelompok budidaya digunakan untuk pembelian pakan. Tujuan pelaksanaan kegiatan pengabdian kepada masyarakat ini adalah untuk membantu pembudidaya ikan dalam memenuhi ketersediaan pakan selama budidaya sehingga dapat menekan biaya pakan yang relatif mahal. Pengabdian masyarakat dilaksanakan pada bulan Juli 2021 yang bertempat di Laboratorium Sistem dan Teknologi Budidaya, Fakultas Perikanan dan IImu Kelautan Universitas Khairun. Metode kegiatan yang dilakukan adalah penyuluhan langsung. Hasil yang diperoleh dari kegaiatan pemberdayaan masyarakat ini yaitu masyarakat atau kelompok budidaya ikan hias (Aqua fish) ini mampu menyerap ilmu yang diperoleh tentang bagaimana membuat pakan mulai dari membuat formulasi, mengenal bahanbahan yang bisa digunakan dalam pembuatan pakan hingga membuat pakan dan diberikan langsung ke ikan budidaya. Pembuatan pakan ikan dapat dilakukan oleh pembudidaya ikan dengan mudah, bahan baku yang digunakan dalam pembuatan pakan dapat diperoleh di wilayah sekitar sehingga mempermudah pembudidaya untuk membuat pakan sendiri tanpa tergantung dari pakan komersial (pabrik), hal ini dapat membantu menekan biaya pakan yang selama ini menjadi masalah ditingkat pembudidaya.
\end{abstract}

Panduan Sitasi (APPA $7^{\text {th }}$ edition) :

Andriani, R., Muchdar, F., Ahmad, K., \& Juharni. (2021). Pemanfaatan Bahan Baku Lokal Sebagai Pakan Ikan Untuk Kelompok Budidaya Ikan Hias (Aqua Fish) Di Kota Ternate. Jurnal Pengabdian Perikanan Indonesia, 1 (3), 231-239. http://doi.org/ 10.29303/jppi.v1i3.455

\section{PENDAHULUAN}


Pengabdian masyarakat merupakan bagian dari program Tri Darma perguruan tinggi yang sejalan dengan penelitian sebagai wujud nyata peranan perguruan tinggi dalam mewujudkan kemajuan bangsa. Perguruan tinggi berkewajiban menyelenggarakan penelitian dan pengabdian kepada masyarakat disamping melaksanakan pendidikan sebagaimana diamanatkan oleh Undang-undang Nomor 20 Tahun 2003 tentang Sistem Pendidikan Nasional Pasal 20. Sejalan dengan kewajiban tersebut, Undang-undang Nomor 12 Tahun 2012 tentang Pendidikan Tinggi Pasal 45 menegaskan bahwa penelitian di perguruan tinggi diarahkan untuk mengembangkan ilmu pengetahuan dan teknologi, serta meningkatkan kesejahteraan masyarakat dan daya saing bangsa. Dalam pasal tersebut juga ditegaskan bahwa pengabdian kepada masyarakat merupakan kegiatan civitas akademika dalam mengamalkan dan membudayakan ilmu pengetahuan dan teknologi untuk memajukan kesejahteraan umum dan mencerdaskan kehidupan bangsa (Renstra PPM Unkhair, 2014-2019).

Pakan merupakan salah satu komponen strategis yang sangat menentukan keberhasilan usaha budidaya. Pada kegiatan tersebut, hampir $60-70 \%$ dari total biaya produksi digunakan untuk pembelian pakan (Haryati, et al. 2009; Haliman dan Dian, 2005). Salah satu faktor penting dalam usaha budidaya adalah penyediaan pakan yang lengkap dengan komposisi nutrien serta jumlah yang sesuai dengan kebutuhan dari ikan/udang. Secara umum kebutuhan dari pakan didalam kegiatan budidaya yang diberikan ialah berupa pakan buatan, akan tetapi pakan buatan yang telah beredar di pasaran memiliki banyak sekali merek serta kemasan dan mempunyai harga yang cukup mahal. Oleh sebab itu sangat perlu diusahakan adanya pakan yang efisien serta harga yang bersaing (Ihwani, 2017). Dalam meningkatkan kualitas, pertumbuhan dan kelulushidupan organisme yang dibudidayakan, tepung ikan umumnya digunakan sebagai sumber protein hewani pada pakan, tetapi ketersediannya masih fluktuatif yang diakibatkan oleh tingginya harga dari tepung ikan tersebut dan masih merupakan komoditas impor. Sehingga, diperlukan pakan alternatif yang kaya akan protein sebagai pengganti tepung ikan (Rumondor, et al, 2016).

Sebagai upaya untuk menekan harga pakan maka perlu dicari alternatif bahan baku yang tersedia sepanjang waktu, sehingga untuk membuat pakan dapat dengan mudah dilakukan kapan saja selama proses budidaya berlangsung. Salah satu bahan pakan alternatif sebagai sumber protein hewani. Limbah ikan yang tersedia setiap saat di pasar ikan yang tidak dimanfaatkan menjadi salah satu alternatif pemanfaatan untuk dijadikan sebagai bahan tambahan pembuatan pakan ikan. bahan tambahan lainnya juga bisa ditemukan disekitar seperti; dedak halus, limbah tahu, tapioka dan vitamin. Dengan memanfaatkan bahan baku yang ada disekitar dapat membantu pembudidaya untuk memproduksi pakan mandiri sehingga dapat menekan biaya pakan.

Tujuan pelaksanaan kegiatan pengabdian kepada masyarakat ini adalah untuk membantu pembudidaya ikan dalam memenuhi ketersediaan pakan selama budidaya sehingga dapat menekan biaya pakan yang relatif mahal serta dapat memanfaatkan bahan baku lokal yang ada disekitar sebagai bahan baku pakan.

\section{METODE KEGIATAN}

Kegiatan pengabdian masyarakat ini dilaksanakan pada bulan Juli, 2021 bertempat di Laboratorium Sistem dan Teknologi Budidaya, Fakultas Perikanan dan Ilmu Kelautan Universitas Khairun dengan melibatkan keterwakilan pelaku usaha budidaya dan mahasiswa program studi budidaya perairan. Alat dan Bahan yg digunakan disajikan pada Tabel 1 dan 2 :

Tabel 1. Alat yang digunakan pada kegiatan pengabdian masyarakat sebagai berikut:

\begin{tabular}{cll}
\hline No & \multicolumn{1}{c}{ Nama Alat } & \multicolumn{1}{c}{ Kegunaan } \\
\hline 1 & Blender & Alat penepungan bahan baku pakan \\
2 & Baskom & Sebagai wadah bahan baku pakan \\
3 & Oven listrik & Sebagai alat pengering pakan \\
\hline
\end{tabular}




\begin{tabular}{|c|c|c|}
\hline 4 & Sendok & Untuk mengambil bahan hasil penepungan. \\
\hline 5 & Nampan & $\begin{array}{l}\text { Sebagai wadah pencetakan dan pengeringan } \\
\text { pakan }\end{array}$ \\
\hline 6 & Plastik & Sebagai wadah penyimpanan pakan \\
\hline 7 & Isolasi & $\begin{array}{l}\text { Sebagai perekat pada sampel bahan baku pakan } \\
\text { untuk di simpan }\end{array}$ \\
\hline 8 & Alat pencetak pakan & Untuk mencetak pakan \\
\hline 9 & Ayakan & Untuk mengayak bahan baku hasil penepungan \\
\hline 10 & Timbangan analitik & Untuk menimbang bahan uji \\
\hline 11 & Ember/Toples & Sebagai wadah bahan pakan \\
\hline 12 & Kertas Label & Label sampel uji pakan \\
\hline 13 & Cutter & Alat untuk memotong pakan \\
\hline
\end{tabular}

Tabel 2. Bahan yang digunakan pada kegiatan pengabdian masyarakat sebagai berikut.

\begin{tabular}{cll}
\hline No & \multicolumn{1}{c}{ Nama Alat } & \multicolumn{1}{c}{ Kegunaan } \\
\hline 1 & Rumput Laut Gracilaria sp & Bahan pakan \\
2 & Tepung Jagung/maizena & Bahan pakan \\
3 & Ikan Teri & Bahan pakan \\
4 & Maggot (Hermetia illucens) & Bahan pakan \\
5 & Dedak halus & Bahan pakan \\
6 & Vitamin & Bahan pakan \\
7 & Spirulina & Bahan pakan \\
8 & Minyak ikan & Bahan pakan \\
9 & Air & Sebagai campuran pakan \\
\hline
\end{tabular}

\section{Tahapan Pelaksanaan :}

1. Pemahaman teori tentang bagaimana menghitung formulasi pakan dan metode pembuatan pakan yang dijelaskan langsung oleh narasumber dalam hal ini dosen program studi budidaya perairan

2. Pengenalan bahan baku pakan yang sudah disiapkan untuk membuat pakan

3. Pencampuran bahan pakan

4. Pembuatan pakan menjadi adonan

5. Proses pencetakan pakan

6. Pengeringan pakan

\section{HASIL DAN PEMBAHASAN}

\section{Pemahaman teori menghitung formulasi pakan}

Pakan buatan adalah pakan yang dibuat dari bahan makanan baik nabati maupun hewani dengan memperhatikan kandungan gizi, sifat dan ukuran ikan. Dengan diberikan pakan buatan maka kebutuhan gizi ikan dapat dipenuhi setiap saat tanpa bergantung pada pakan alami yang ada. Sebelum melakukan pembuatan pakan ikan harus dipahami terlebih dahulu tentang jenis-jenis pakan yang dapat diberikan kepada ikan budidaya. Pengelompokan jenis-jenis pakan ikan dapat dibuat berdasarkan bentuk, berdasarkan kandungan airnya, berdasarkan sumber dan berdasarkan konstribusinya pada pertumbuhan ikan. Bentuk pakan dan kandungan bahan pakan juga mempengaruhi tingkat pertumbuhan ikan yang dibudidaya.

Pemahaman teori formulasi pembuatan pakan bertujuan untuk mempelajari seberapa banyak pakan yang akan dibuat dan seberapa banyak jumlah bahan yang akan digunakan, selain itu juga hal yang paling penting dalam penentuan formulasi pakan ialah seberapa banyak kandungan protein yang 
diinginkan atau diharapkan. Hal ini penting dilakukan supaya dalam proses pembuatan pakan tidak terjadi kesalahan dalam penentuan jumlah bahan baku pakan pada saat pencampuran.

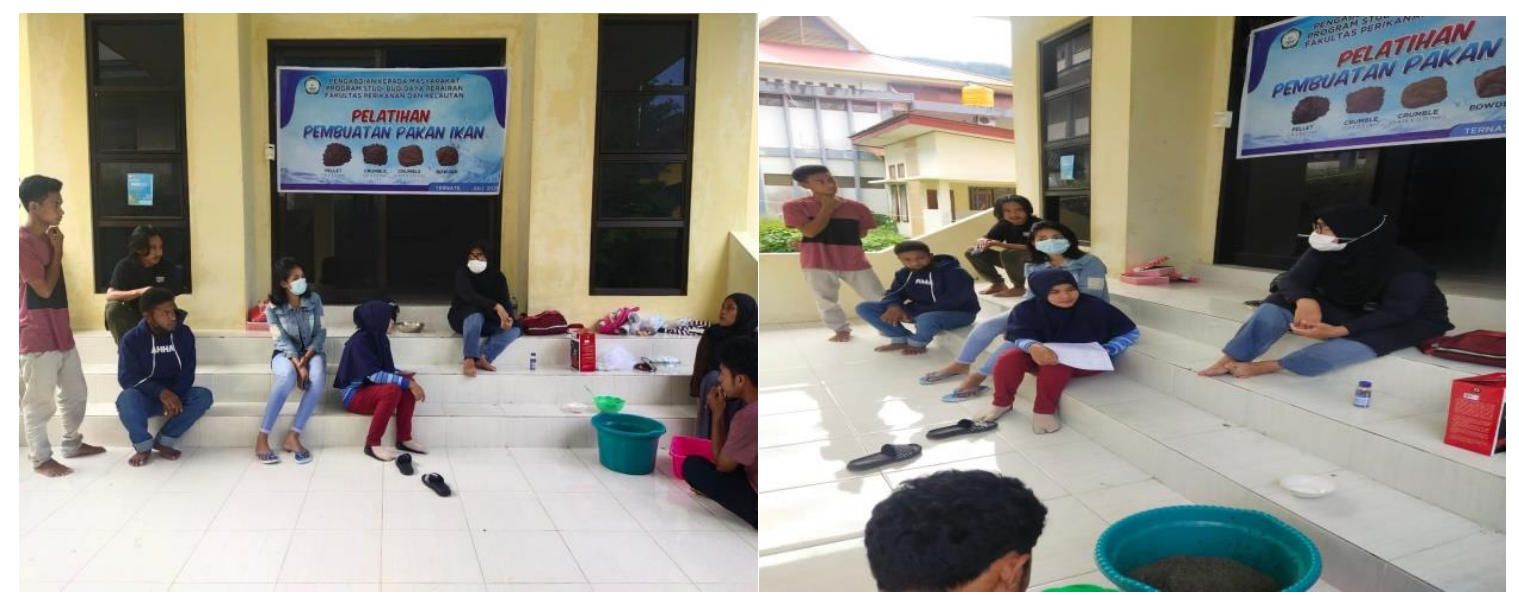

Gambar 1. Pemahaman teori yang disampaikan langsung oleh dosen program studi budidaya perairan

Komposisi pakan buatan disusun berdasarkan kebutuhan zat gizi setiap jenis biota air. Komposisi ini sering disebut formulasi pakan. Formulasi yang baik berarti mengandung semua zat gizi yang diperlukan ikan dan secara ekonomis murah serta mudah diperoleh sehingga memberikan keuntungan. Penyusunan formulasi pakan harus memperhatikan nilai kandungan protein karena zat ini merupakan komponen utama untuk pertumbuhan ikan. Setelah diketahui kandungan protein dari pakan yang akan dibuat, maka langkah selanjutnya adalah perhitungan untuk komponen zat- zat gizi yang lain, seperti karbohidrat dan lemak. Formulasi pakan di buat dengan menggunakan Metode Pearson's Square (segi empat Pearson). Dasar dalam penyusunan formulasi pakan menggunakan metode ini adalah adanya pembagian tingkatan protein bahan-bahan pakan. Tingkatan tersebut dibagi menjadi 2 , yaitu protein basal dan protein suplemen. (BRSDMKP, 2021). Protein yang dikehendaki dalam pembuatan pakan ini yaitu $35 \%$. Perhitungannya adalah sebagai berikut :

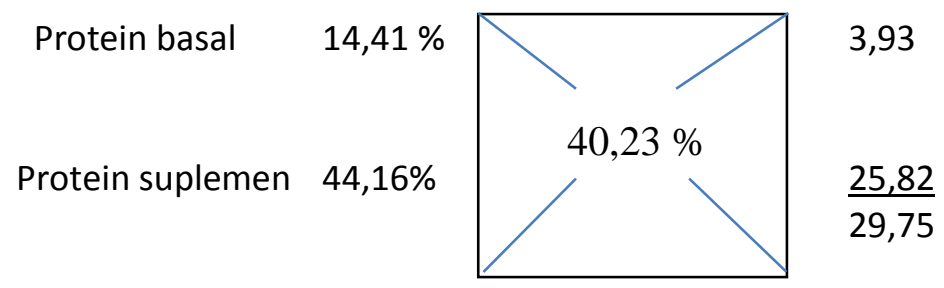

Tabel 3. Pengelompokan bahan-bahan pakan ke dalam bahan baku utama dan tambahan/pelengkap.

\begin{tabular}{lc}
\hline \multicolumn{1}{c}{ Jenis Bahan Baku } & $\begin{array}{c}\text { Kandungan Protein dalam } \\
\text { Bahan (\%) }\end{array}$ \\
\hline Bahan Tambahan : & \\
Tepung maizena 10\% & \\
Vitamin 3 \% & \\
\hline Jumlah bahan tambahan : 10\%+ 3\% = 13\% & \\
\hline Bahan Utama : & 32,5 \\
Tepung ikan teri & 45 \\
Tepung maggot & 55 \\
Spirulina & \\
\hline
\end{tabular}




\begin{tabular}{lc}
\hline Tepung dedak halus & 12 \\
Rumput laut & 16,83 \\
\hline Jumlah bahan utama $=\mathbf{1 0 0 \% - 1 3 \% = \mathbf { 8 7 } \%}$ & \\
\hline
\end{tabular}

Tabel 4. Rata-rata protein Basal dan Suplemen :

\begin{tabular}{cclc}
\hline \multicolumn{2}{c}{ Protein Basal (\%) } & \multicolumn{2}{c}{ Protein Suplemen (\%) } \\
\hline Dedak halus & 12 & T. Ikan teri & 32,5 \\
Rumput laut & 16,83 & T. Maggot & 45 \\
& & Spirulina & 55 \\
\hline Jumlah & $\mathbf{2 8 , 8 3}$ & Jumlah & $\mathbf{1 3 2 , 5}$ \\
\hline Rata-rata & $\mathbf{1 4 , 4 1 5}$ & Rata-rata & $\mathbf{4 4 , 1 6}$ \\
\hline
\end{tabular}

Tabel 5. Komposisi protein bahan baku.

\begin{tabular}{lccc}
\hline Nama bahan & $\begin{array}{c}\text { Kandungan protein } \\
\text { dalam bahan baku } \\
(\mathbf{\% )}\end{array}$ & $\begin{array}{c}\text { Jumlah bahan yang } \\
\text { dibutuhkan } \\
(\mathbf{\% )}\end{array}$ & $\begin{array}{c}\text { Hasil kali } \\
\text { (\%) }\end{array}$ \\
\hline T. Ikan teri & 32,5 & 25,16 & 8,17 \\
T. Maggot & 45 & 25,16 & 11,32 \\
Spirulina & 55 & 25,16 & 13,83 \\
T. Dedak halus & 12 & 5,74 & 0,7 \\
Rumput Laut & 16,83 & 5,74 & 0,96 \\
\hline \multicolumn{4}{c}{} \\
\hline
\end{tabular}

\section{Pengenalan bahan baku pakan}

Bahan baku pakan yang digunakan adalah bahan baku yang ada di seputaran Kota Ternate, bahanbahan tersebut relatif murah dan mudah di dapat. Bahan-bahan yang digunakan antara lain; Maggot merupakan hasil kultur dari kegiatan praktek mahasiswa, rumput laut diperoleh dari perairan pantai di Kelurahan Sasa yang tidak jauh dari lokasi pengabdian, ikan teri dan bahan lainnya diperoleh dari pasar tradisional dan toko yang berada disekitar lokasi pengabdian masyarakat.

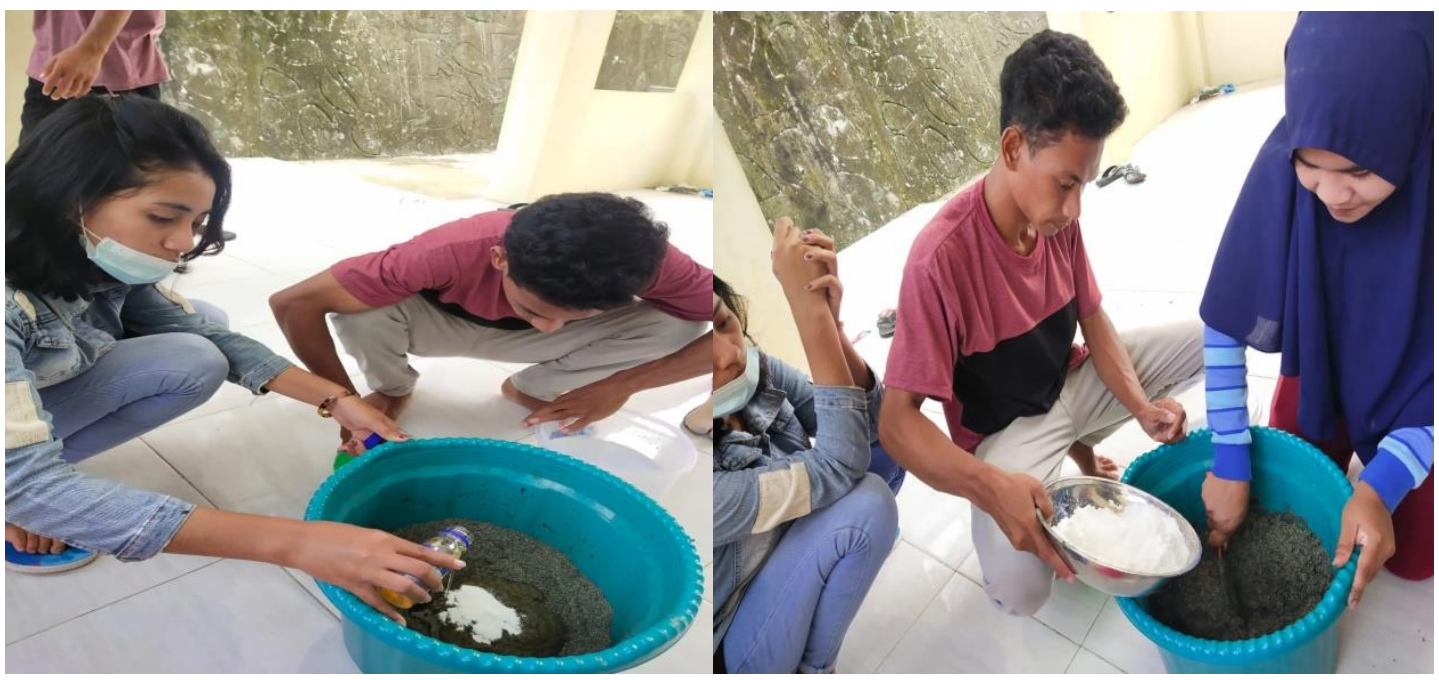

Gambar 2. Pengenalan bahan baku pakan dan Pencampuran Bahan Pakan 
Bahan baku pakan dapat berasal dari nabati (tumbuhan) maupun hewani (hewan). Pertimbangan pemilihan bahan baku antara lain; ketersediaan bahan baku pakan tidak bersaing dengan kebutuhan manusia dan harga pakan relatif murah dan terjangkau. Sebagaimana dalam pembuatan pakan, bahan yang digunakan juga harus memenuhi syarat sebagai pakan ikan Apabila dilihat dari segi ekonomi, pengurangan pellet atau pakan komersil/pabrikan dapat meningkatkan keuntungan karena bahan-bahan subtitusinya relative murah dan mudah diperoleh.

\section{Proses Pencampuran Bahan Pakan}

Proses pencampuran bahan pakan dilakukan setelah dilakukan penimbangan bahan pakan dan dihitung berdasarkan formulasi yang telah dibuat sebelumnya. Berdasarkan formulasi tersebut pakan yang akan dibuat memiliki kandungan protein 35\% dan jumlah pakan yang akan dibuat sebanyak $1 \mathrm{~kg}$ pakan. Seluruh bahan dicampur secara merata dan homogen agar seluruh bagian pakan yang dihasilkan mempunyai komposisi zat gizi yang merata dan sesuai dengan formulasi. Pencampuran bahan-bahan dilakukan secara bertahap mulai dari bahan yang volumenya paling besar hingga bahan yang volumenya paling kecil. Pencampuran bahan baku dilakukan pada wadah atau baskom dan pengadukannya dilakukan dengan menggunakan tangan.

Setelah semua bahan homogen, selanjutnya ditambahkan air sebanyak $500 \mathrm{ml}$ dengan tujuan supaya bahan dapat tercampur dengan rata hingga membentuk adonan.

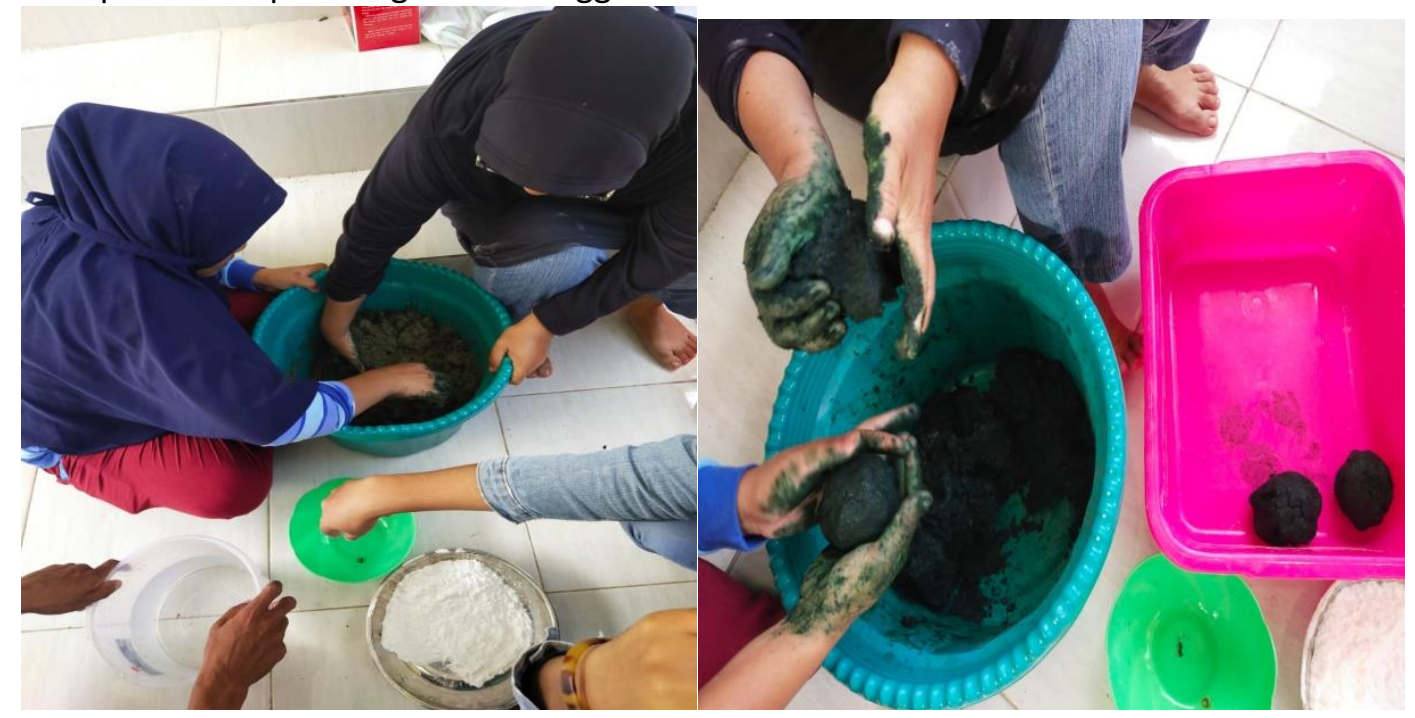

Gambar 3. Proses pencampuran dan pembentukan pakan

\section{Proses pencetakan pakan}

Pencetakan pakan merupakan tahapan lanjutan setelah adonan pakan dibuat. Pencetakan pakan dapat menggunakan mesin. Mesin pencetak pakan sendiri terbagi menjadi 2 yaitu mesin pakan yang digerakkan dengan mesin (dinamo/diesel) dan mesin yang digerakkan dengan tenaga manusia (manual). Sebelum melakukan pencetakan, terlebih dahulu menentukan ukuran diameter lubang cetakan pakan sesuai dengan yang ditentukan. mesin pakan yang digunakan pada pelatihan pembuatan pakan ini menggunakan mesin pakan manual yaitu mesin penggiling daging, selanjutnya setelah pakan tercetak maka dilakukan pemotongan pakan disesuaikan dengan ukuran ikan dan bukaan mulut ikan. 


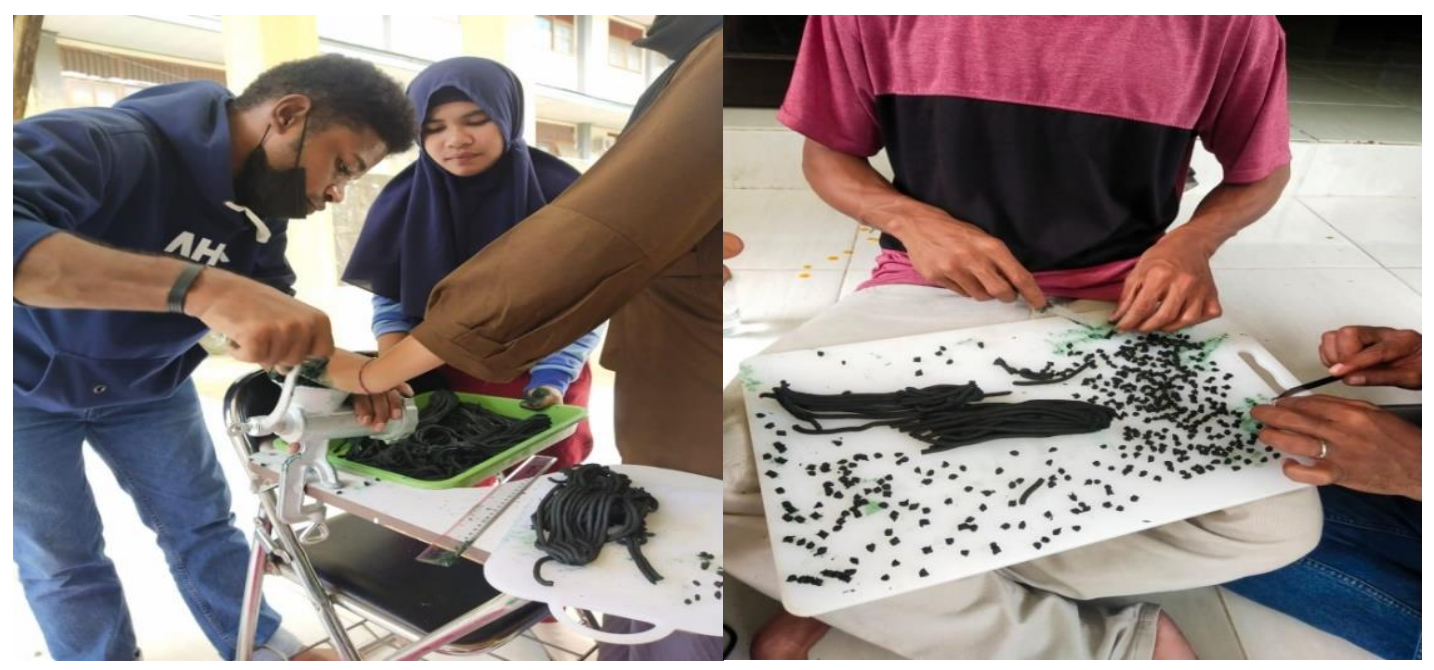

Gambar 4. Proses pencetakan pakan

\section{Pengeringan pakan}

Tujuan pengeringan adalah agar pakan yang dihasilkan dapat disimpan dalam waktu yang lama dan mengurangi volume serta berat dari pakan yang dihasilkan sehingga akan menambah daya apung pakan ketika akan diberikan. Proses pengeringan dilakukan secara alami dengan mengandalkan sinar matahari lamgsung selama 2 hari.
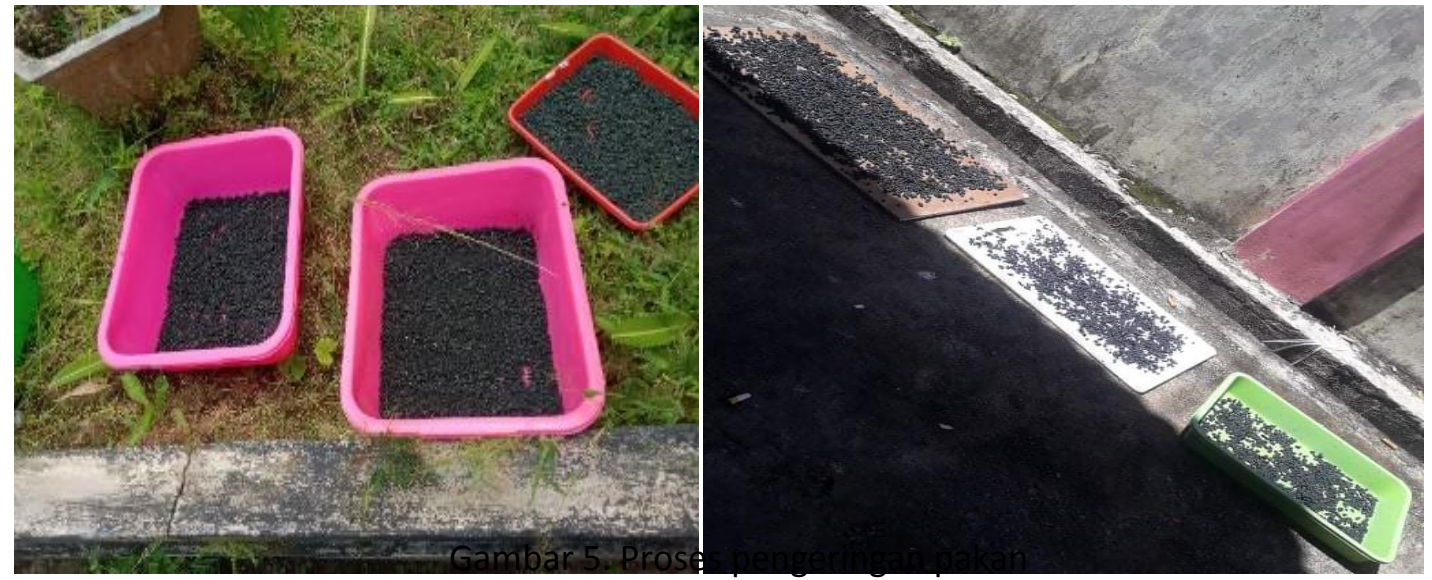

Pengeringan pada intinya adalah mengeluarkan kandungan air di dalam pakan menjadi kurang dari $14 \%$, sesuai dengan syarat mutu pakan ikan pada umumnya. Proses pengeringan perlu dilakukan apabila pencetakan dilakukan dengan mesin sederhana. Jika pencetakan dilakukan dengan mesin pellet sistem kering, cukup dikering anginkan saja hingga uap panasnya hilang, sehingga pellet menjadi kering dan tidak mudah berubah kembali ke bentuk tepung. Pengeringan dapat dilakukan secara alami dengan bantuan sinar matahari dan secara mekanik dengan bantuan alat (oven) pengering. Kedua cara tersebut tentu mempunyai kelebihan dan kelemahan. Pengeringan secara alami, misalnya, tidak memerlukan biaya investasi dan operasional alat, tetapi sangat bergantung kepada terik sinar matahari dan diperlukan lahan untuk penjemuran. Sebaliknya, jika digunakan alat pengeringan, maka diperlukan biaya investasi dan operasional alat, tetapi pengeringan dapat dikerjakan di setiap waktu tanpa terikat musim, luas lahan yang dibutuhkan untuk pengeringan dapat ditekan, suhu lebih mudah diatur sesuai keinginan. (BRSDMKP, 2021) 


\section{KESIMPULAN DAN SARAN}

Pembuatan pakan ikan dapat dilakukan oleh pembudidaya ikan dengan mudah, bahan baku yang digunakan dalam pembuatan pakan dapat diperoleh di wilayah sekitar sehingga mempermudah pembudidaya untuk membuat pakan sendiri tanpa tergantung dari pakan komersial (pabrik), hal ini dapat membantu menekan biaya pakan yang selama ini menjadi masalah ditingkat pembudidaya.

Dengan adanya pengabdian masyarakat tentang teknik pembuatan pakan buatan ini diharapkan pembudidaya dapat membuat pakan sendiri sehingga tidak bergantung pada pakan komersil, hasilnya dapat juga dijadikan peluang usaha dalam memproduksi pakan sehingga dapat menambah penghasilan keluarga.

\section{DAFTAR PUSTAKA}

Badan Riset Sumber Daya Manusia Kelautan dan Perikanan (BRSDMKP). Pusat Pelatihan Kelautan dan Perikanan Balai Pelatihan dan Penyuluhan Perikanan Bitung, 2021. Bahan Ajar Pelatihan Pembuatan Pakan Ikan Buatan. Kementrian Kelautan dan Perikanan Jakarta.

Haliman, R.W. dan Dian, A.S, 2005. Udang vannamei (Litopenaeus vannamei):pembudidayaan dan prospek pasar udang putih yang tahan penyakit.Penebar Swadaya, Jakarta.

Haryati, E. S dan Zainuddin. 2009. Formulasi dan aplikasi pakan untuk induk dan pembesaran: Aplikasi pakan buatan untuk peningkatan kualitas induk udang windu lokal. Laporan Penelitian Hibah Kompetitif Penelitian Prioritas Nasional.

Ihwani M, 2017. Pengaruh Frekuensi Pemberian Pakan Yang Berbeda Terhadap Pertumbuhan Tokolan Udang Vaname (Litopenaeus vannamei) Di Keramba Jaring Apung (Kja). Universitas Brawijaya Malang. HIm 1.

Unkhair, 2019. Renstra Pengabdian Kepada Masyarakat Universitas Khairun Tahun 2014-2019.

Rumondor, G., K. Maaruf, Y.R.L. Tulung, F.R. Wolayan. 2016. Pengaruh Penggantian Tepung Ikan dengan Tepung Maggot Black Soldier (Hermetia illucens) dalam Ransum Terhadap Persentase Karkas dan Lemak $\quad$ Abdomen Broiler. Jurnal Zootek. 36 (1): 131-138. 